Journal of English Language Teaching

\title{
Teacher Social Competence, Student Learning Motivation, and Learning Outcomes in English Subject
}

\section{Qurrot Ainy, Hendi Pratama ${ }^{凶}$}

English Department, Faculty of Languages and Arts, Universitas Negeri Semarang, Indonesia

\begin{tabular}{l} 
Article Info \\
\hline Article History: \\
Received in 3 April \\
2020 \\
Approved in 1 June \\
2020 \\
Published in 30 July \\
2020 \\
\\
\hline Keywords: Teacher Social \\
Competence; Learning \\
Motivation; Learning \\
Outcomes
\end{tabular}

Outcomes

\begin{abstract}
This study aimed to investigate the correlation between teacher social competence, student learning motivation, and learning outcomes in English subject. The population of this study is all the students of Junior High School 1 Purbalingga academic year 2019/2020. The sample in this study is 90 students. The sampling technique is stratified convience sampling. In collecting data, there were some research instruments used; questionnaires and documentation. The research data were analyzed by Peason product-moment correlation. Based on the analysis and statistical quantification, it was found that the results of the study were (1) there is a positive and significant correlation between teacher social competence and student learning outcomes as shown by the value of Pearson correlation coefficient 0.919 ; (2) there is a positive and significant correlation between student learning motivation and student learning outcomes as shown by the value of Pearson correlation coefficient 0.908; (3) there is a positive and significant correlation between teacher social competence and student learning motivation as shown by the value of Pearson correlation coefficient 0.994 . In conclusion, teachers' social competence correlation is higher than students learning motivation. Therefore, the teachers should work on their social skill to improve student learning outcomes. On the other hand, the students needs to motivate themselves.
\end{abstract}

\footnotetext{
Correspondent Address:

B3 Building FBS Unnes

Sekaran, Gunungpati, Semarang, 50229

E-mail: aqurrot@gmail.com, hendipratma@mail.unnes.ac.id
} 


\section{INTRODUCTION}

The quality of education in Indonesia is still far from adequate. Based on the Global Education Monitoring Report from UNESCO data in 2016, the teacher in Indonesia ranked $14^{\text {th }}$ out of 14 developing countries. Moreover, from the Teacher Competency Test in 2015 results, the national average is only 44.5 far below the 75 standard. While according to the study conducted by Chang et al. (2014) both certified and uncertified teachers have no impact on student learning outcomes.

The teacher is associated closely with student in the implementation of education on daily. In carrying out the task the teacher must have competence. Minister of National Education Regulation number 16 of 2007 regarding academic qualification standards and teacher competencies explains that every teacher must meet the teacher competency qualification. The teacher should have four competencies such as professional, pedagogy, personality, and social competence (Uno \& Lamatenggo, 2016). Social competence is needed to attract students' interest in teaching and learning sessions. Social competence is the teacher's ability to communicate and interact effectively and efficiently with students, peers/professionals, parents of students, and society moreover does not discriminate against ethnicity, race, and language (Kunandar, 2014). To have the best learning outcomes the student must have high learning motivation. Learning motivation is an impulse for someone to do something and achieve a goal and that is learning outcomes (Uno, 2007). Learning outcome is the goal of the studies to be achieved and product from the learning process which can be seen from the improvement of the behavior obtained after the process of learning (Anni, 2004). Learning outcomes for the students are an improvement of mental development after learning activities include cognitive, affective, and psychomotor, while for the teachers are the completion of the learning material that has been delivered (Mudjiono, 2006).

The principle underlying the assessment of learning outcomes is to provide hope for students and teachers to be able to improve the quality of learning (Mansur, 2009). Quality in the sense that students become effective learners and teachers become good motivators. In this case, the learning outcomes become the reason for determining the next steps to solve the problems so the students can improve their learning.

Four teacher competencies such as pedagogical, personal, professional, and social partially influence the learning performance also simultaneously and significantly in improving the quality of performance in the learning process (Hakim, 2015). Muda'i (2017) states learning motivation is a complex thing, many factors might affect this. Musriana (2018) states teachers as a motivator toward student learning outcomes. A competent teacher with a good environment improving the student learning motivation (Tabi' in, 2016). A study conducted by Mappeasse (2009) revealed the way students learn and their motivation to learning affected their learning outcomes. While Bernaus and Gardner (2008) stated that the language teaching strategies on students' motivation were on relative frequency while English achievement is not correlated. Wardani et al. (2018) attempt to ascertain whether there is an influence and how big it is of social competence on student learning motivation at XI grade students of accounting of Vocational High School 7 Pontianak. The result of the study revealed after done simpe linear regression on the variables of $\mathrm{x}$ and $\mathrm{y}$ said that social competence has a negative influence on student learning motivation with $23 \%$ the other $77 \%$ was affected by another factor that was not examined in this study.

Problems investigated in this research are (1) what is the correlation between teacher social competence and student learning outcomes in English subject at junior high school? (2) what is the correlation between student learning motivation and student learning outcomes in English subject at junior high school? (3) what is the correlation between teacher social competence and student learning motivation in English subject at junior high school?

From the studies above, there have been many researchers who conducted studies about teacher competence and student learning motivation in English subject separately. My research is different from the previous research upon the details of the research. In my research, I will concern to investigate the correlation between teacher social competence and student learning motivation on student learning outcomes in English subject at Junior High School. Objectives of this study are (1) to investigate the correlation between teacher social competence and student learning outcomes in English subject at junior high school, (2) to investigate the correlation between student learning motivation and student learning outcomes in English subject at junior high school, (3) to investigate the correlation between teacher social competence and student learning motivation in English subject at junior high school.

\section{METHODS}

This research focuses on the the correlation between teacher social competence and student learning motivation on student learning outcomes. Research variables of this study are teacher social competence $\left(X_{1}\right)$ and student learning motivation $\left(X_{2}\right)$ as independent variable. The dependent variable in this study is student learning outcomes $(\mathrm{Y})$. This research used quantitative method. Quantitative is a type of data that can be 
calculated which contains information or explanations expressed with a number (Sugiyono, 2010). In this research, the source of quantitative data is from the questionnaire. A questionnaire as a research tool includes a set of questions or any other types of prompts aimed at collecting information from a respondent (Adi, 2019). The type of questionnaire here is a structured questionnaire. The type of questions in the questionnaire that the researcher used in this study is close-ended questions. Both of the questionnaire is quantitative for 90 respondent. Type of the data in the instrument is index. One datum is one index comes from one of the respondent. Minimum index is 1 and maximum index is 4 . The instrument for teacher social competence is 15 items, while the instrument for learning motivation is 30 items. The total of the data is 90 .

The research was conducted a study at Junior High School State 1 Purbalingga. The sampling technique is stratified convenience sampling. The sample was chosen from each level proportionally and then was divided into strata (Sugiyono, 2015). Convenience sampling is a method where the main data source available without additional requirements, there is no criterion for inclusion defined before selecting the subject (Dudovskiy, 2016). The research takes 30 students for each grade to be the sample. The total of the sample was 90 students.

After all the data gathered, the next step is analyzing the data. In this research, the data are analyzed using statistic method because the process of compiling the data, draw a conclusion, and making a decision arranged systematically. Statistical functions used in this study include validity, reliability, normality, and linearity.

Validity is defined as showing the suitability, compatibility, usefulness of specific conclusions that have been made based on research data that has been collected. With the validity of the instrument, strong evidence has been carried out to support the conclusion of the instrument. The validity tested in this study is content validity. To measure the content validity, the internal consistency method is used to measure the magnitude of the correlation between each item and all statement items using the product-moment correlation formula. The decision is based on the number of $r$ quantification. The data is valid if $r$ quantification $>\mathrm{r}$ table (Sujarweni, 2014). The value of $r$ table based on the value of df (degree of freedom) in the research. The formula of $\mathrm{df}$ is $\mathrm{N}-2$. $\mathrm{N}$ is the total of the respondent.

The test of reliability is done to know the accuracy of the research instrument (Sujarweni, 2014). The reliability test of the questionnaire to determine whether it is a good questionnaire to gather the data. To test the reliability the researcher use SPSS 23 for Windows. The decision based on the value of Cronbach alpha. The data is reliable if the number of Cronbach alpha $>0.60$.

The normality test aims to determine whether the sample taken comes from populations that are normally distributed or not, so it will be more accurate and effective (Pratama, 2019). To test the normality, the researcher using Kolmogorov-Smirnov. The data was analyzed with the help of SPSS 23 for windows. The decision is based on the number of Asymp. Sig. (2-tailed). If the number of Asymp. Sig. more than 0.05, the data is normally distributed.

This linearity test aims to see whether the linearity of the two variables is significant or not (Widiyanto, 2012). To detect the correlation between the regression equation and the linearity test of the regression line needed help by looking at linearity in the Anova table of SPSS 23 for windows. If the significance of the linearity is less than 0.05 then the variable is stated linear. The decision was also based on the significance of deviation from linearity, it must be more than 0.05 . The f quantification $<\mathrm{f}$ table. The distribution of the $\mathrm{f}$ table was based on the number of $\mathrm{df}$ (degree of freedom).

The hypotheses tested in this study are the influence of independent variables namely the teacher's social competence $\left(X_{1}\right)$, student learning motivation $\left(X_{2}\right)$ to the dependent variable student learning outcomes (Y). To do the calculation and analysis used a computer program that is Microsoft Excel and SPSS 23 for windows. The test of the hypothesis using Pearson's Correlation Coefficient. Correlation is a technique for investigating the relationship between two variables (Pratama, 2019). Pearson's correlation coefficient (r) is measure of the strength of the relationship between the two variables. With help of SPSS 23 for windows this test aims to test the first and second hypotheses. The result will show up in the table of model summary. To determine an interpretation of the result correlation coefficients, it can be seen in the list below based on Nangolo and Musingwini (as cited in Pratama, 2019):

Table 1. Interpretation The Power in Correlation Test

\begin{tabular}{cc}
\hline Coefficient Range & Power of Correlation \\
\hline $0.00-0.30$ & Weak \\
$0.31-0.50$ & Medium \\
$0.51-0.80$ & Strong \\
$0.81-1.00$ & Very Strong \\
\hline
\end{tabular}


The significant correlation marked by a symbol $(* *)$, if the correlation is not really strong marked by only one $\left({ }^{*}\right)$, and there will be no symbol $\left({ }^{*}\right)$ if the correlation is weak. After that to test the hypothesis based on the condition as follows:

The correlation $X_{1}$ and $X_{2}$ toward $Y$ is partial

$\mathrm{H} 0:=0$, means $X_{1}$ and $X_{2}$ partially not correlate significantly toward $\mathrm{Y}$

$\mathrm{H} 0: \neq 0$, means $X_{1}$ and $X_{2}$ partially correlate significantly toward $\mathrm{Y}$

Based on the result of correlation coefficient and the symbol $(*)$ the decision was made.

\section{FINDINGS AND DISCUSSION}

The data for this study was gathered by distributing the questionnaire at Junior High School 1 Purbalingga. The researcher came into class seven, eight, and nine with a total of 90 students as the sample. The students were filling up the questionnaire by giving a checklist for each statement. For the questionnaire about teacher social competence, there is 15 items. For the questionnaire about student learning motivation is 30 items. Each answer of the item changed into a number, for positive statement strongly agree is 4 , agree 3 , disagree 2 , and strongly disagree is 1 , while the negative statement is reversed. The researcher attained the learning outcomes in the cognitive area from the report book first term academic year 2019/2020.

After all the data were collected, the researcher conducted the test of validity, reliability, and linearity as a requirement before the test of the hypotheses. The test used SPSS 23 for Windows. The result of research instruments validation test were valid shown in table 2 and 3 below:

Table 2. The Result of $X_{1}$ Validation Test

\begin{tabular}{ccc}
\hline Item & r quant. & $\begin{array}{c}\text { r table } \\
5 \%\end{array}$ \\
\hline 1 & 0.518 & 0.205 \\
2 & 0.384 & 0.205 \\
3 & 0.422 & 0.205 \\
4 & 0.506 & 0.205 \\
5 & 0.457 & 0.205 \\
6 & 0.490 & 0.205 \\
7 & 0.359 & 0.205 \\
8 & 0.444 & 0.205 \\
9 & 0.544 & 0.205 \\
10 & 0.317 & 0.205 \\
11 & 0.535 & 0.205 \\
12 & 0.478 & 0.205 \\
13 & 0.389 & 0.205 \\
14 & 0.390 & 0.205 \\
15 & 0.462 & 0.205 \\
\hline
\end{tabular}

Table 3. The Result of $X_{2}$ Validation Test

\begin{tabular}{lrc}
\hline Item & r quant. & $\begin{array}{c}\text { r table } \\
5 \%\end{array}$ \\
\hline 1 & 0.518 & 0.205 \\
2 & 0.384 & 0.205 \\
3 & 0.422 & 0.205 \\
4 & 0.506 & 0.205 \\
5 & 0.457 & 0.205 \\
6 & 0.490 & 0.205 \\
7 & 0.359 & 0.205 \\
8 & 0.444 & 0.205 \\
9 & 0.544 & 0.205 \\
10 & 0.317 & 0.205 \\
11 & 0.535 & 0.205 \\
12 & 0.478 & 0.205 \\
13 & 0.389 & 0.205 \\
14 & 0.390 & 0.205 \\
\hline
\end{tabular}




\begin{tabular}{lll}
\hline 15 & 0.462 & 0.205 \\
16 & 0.513 & 0.205 \\
17 & 0.336 & 0.205 \\
18 & 0.424 & 0.205 \\
19 & 0.528 & 0.205 \\
20 & 0.482 & 0.205 \\
21 & 0.506 & 0.205 \\
22 & 0.385 & 0.205 \\
23 & 0.447 & 0.205 \\
24 & 0.541 & 0.205 \\
25 & 0.210 & 0.205 \\
26 & 0.522 & 0.205 \\
27 & 0.494 & 0.205 \\
28 & 0.412 & 0.205 \\
29 & 0.342 & 0.205 \\
30 & 0.467 & 0.205 \\
\hline
\end{tabular}

The data will be valid if $r$ quantification $>r$ table (Sujarweni, 2014). The value of $r$ table based on total of the respondent $(\mathrm{N})$. In this research $\mathrm{N}=90$. The distribution of $\mathrm{r}$ table product moment for $\mathrm{N} 90$ at $5 \%$ signification is 0,205 . In table 2 and 3 all items of the research instruments are valid. The questionnaire about teacher social competence and learning motivation in table 4 is reliable because the number of Cronbach alpha $>0.60$ (Sujarweni, 2014). All of the items of the research instrument are reliable. In conclusion, it's a good instrument to gather the data.

Table 4. The Result of Reliability Test

\begin{tabular}{cc}
\hline Variable & Crobach Alpha \\
\hline Teacher Social & 0.711 \\
Competence & 0.857 \\
Learning Motivation & \\
\hline
\end{tabular}

Before the test of the hypotheses, the data that have been stated as valid and reliable still need to do normality and linearity test. The purpose of normality and linearity test is to discover whether the distribution of the data is normal and linier or not. The result of normality test shown in table 5 below:

Table 5. The Result of Normality Test

\begin{tabular}{llc}
\hline & & $\begin{array}{c}\text { Unstandardized } \\
\text { Residual }\end{array}$ \\
\hline $\mathrm{N}$ & Mean & 90 \\
Normal & .0000000 \\
Parameters ${ }^{\mathrm{a}, \mathrm{b}}$ & Std & 1.54202805 \\
& Deviation & .090 \\
Most Extreme & Absolute & .090 \\
Differences & Positive & -.079 \\
Test Statistic & Negative & .090 \\
\multicolumn{2}{l}{ Asymp. Sig. (2-tailed) } & $.068^{\circ}$ \\
\hline
\end{tabular}

The decision based on the number of significance. If it's more than 0.05 then the data is normally distributed (Pratama, 2019). As shown in the table Kolmogorov-Smirnov Sig $0.068>0.05$. It can be conclude that the data is distributed normally.

The result of linearity test based on ANOVA table. The variable teacher social competence $\left(X_{1}\right)$ and student learning outcomes $(\mathrm{Y})$ is linear because the significance of the linearity is $0.000<0.05$, the significance of deviation from linearity is $0.278>0.05$, the $\mathrm{f}$ quantification $2.186<\mathrm{f}$ table 2.280 . The $\mathrm{f}$ table based on $\mathrm{df}$ that is 16 and 71 . The $\mathrm{f}$ table for $\mathrm{df} 16$ and 71 is 2.280 . 
Table 6. The result of $X_{1}$ and Y Linearity Test

ANOVA Table

\begin{tabular}{|c|c|c|c|c|c|c|c|}
\hline & & & $\begin{array}{l}\text { Sum of } \\
\text { Squares }\end{array}$ & df & $\begin{array}{l}\text { Mean } \\
\text { Square }\end{array}$ & $\mathrm{F}$ & Sig. \\
\hline \multirow{5}{*}{$\begin{array}{l}\text { Learning } \\
\text { Outcomes * } \\
\text { Teacher Social } \\
\text { Competence }\end{array}$} & Between & (Combined) & 1257.652 & 18 & 69.870 & 37.229 & .000 \\
\hline & Groups & Linearity & 1175.139 & 1 & 1175.139 & 626.164 & .000 \\
\hline & & $\begin{array}{l}\text { Deviation } \\
\text { from Linearity }\end{array}$ & 82.513 & 16 & 4.854 & 2.186 & .278 \\
\hline & \multicolumn{2}{|c|}{ Within Groups } & 133.248 & 71 & 1.877 & & \\
\hline & \multicolumn{2}{|c|}{ Total } & 1390.900 & 89 & & & \\
\hline
\end{tabular}

Based on table 7 the variable student learning motivation $\left(X_{2}\right)$ and student learning outcomes $(Y)$ are linear because the significance of the linearity is $0.000<0.05$, the significance of deviation from linearity is $0.197>0.05$, the $\mathrm{f}$ quantification $1.402<\mathrm{f}$ table 1.670 . The $\mathrm{f}$ table based on $\mathrm{df}$ that is 30 and 55 . The $\mathrm{f}$ table for df 30 and 55 is 1.670 .

Table 7. The result of $X_{2}$ and Y Linearity Test

ANOVA Table

\begin{tabular}{|c|c|c|c|c|c|c|c|}
\hline & & & $\begin{array}{l}\text { Sum of } \\
\text { Squares }\end{array}$ & $\mathrm{df}$ & $\begin{array}{l}\text { Mean } \\
\text { Square }\end{array}$ & $\mathrm{F}$ & Sig. \\
\hline \multirow{5}{*}{$\begin{array}{c}\text { Learning } \\
\text { Outcomes * } \\
\text { Learning } \\
\text { Motivation }\end{array}$} & $\begin{array}{l}\text { Between } \\
\text { Groups }\end{array}$ & $\begin{array}{l}\text { (Combine } \\
\text { d) }\end{array}$ & 1290.733 & 34 & 37.963 & 20.845 & .000 \\
\hline & & Linearity & 1146.384 & 1 & 1146.384 & 629.462 & .000 \\
\hline & & $\begin{array}{l}\text { Deviation } \\
\text { from } \\
\text { Linearity }\end{array}$ & 144.349 & 30 & 4.374 & 1.402 & .197 \\
\hline & Within & Groups & 100.167 & 55 & 1.821 & & \\
\hline & & & 1390.900 & 89 & & & \\
\hline
\end{tabular}

After the data stated as valid, reliable, distributed normally, and linier, the data could be use to test the hypotheses. The result of the hypotheses based on Pearson's correlation coefficient. The result of the test explained below:

\section{Teacher Social Competence Correlate with Learning Outcomes}

The first hypothesis is there is a significant correlation between teacher social competence $\left(X_{1}\right)$ and student learning outcomes $(\mathrm{Y})$ in English subject. The hypothesis analyzed based on Pearson's correlation coefficient in table 8 . The correlation ( $\mathrm{r}$ ) is 0.919 which is very strong. Marked by $\left.{ }^{* *}\right)$ means the correlation is significant. In conclusion the first hypothesis that there is significant correlation between teacher social competence on learning outcomes accepted.

Table 8. Coefficients Correlation and Signification Test $X_{1}$ toward Y

\begin{tabular}{llrr}
\multicolumn{4}{c}{ Correlations } \\
\hline Teacher Social & $\begin{array}{c}\text { Teacher Social } \\
\text { Competence }\end{array}$ & $\begin{array}{c}\text { Learning } \\
\text { Outcomes }\end{array}$ \\
Competence & Pearson Correlation & 1 & $.919^{* *}$ \\
& Sig. (2-tailed) & .000 \\
Learning Outcomes & 90 & 90 \\
& $\mathrm{~N}$ & $.919^{* *}$ & 1 \\
& Pearson Correlation & .000 & 90 \\
& Sig. (2-tailed) & 90 & \\
& $\mathrm{~N}$ & &
\end{tabular}




\section{Student Learning Motivation Correlate with Learning Outcones}

The second hypothesis is there is a correlation and significant between student learning motivation $\left(X_{2}\right)$ and student learning outcomes $(\mathrm{Y})$ in English subject. The hypothesis analyzed based on Pearson's correlation coefficient in table 9 . The correlation is 0.908 which is very strong. Marked by $\left({ }^{* *}\right)$ means the correlation is significant. In conclusion the second hypothesis that there is significant correlation between learning motivation on learning outcomes accepted.

Table 9. Coefficients Correlation and Signification Test $X_{2}$ toward Y

\begin{tabular}{|c|c|c|c|}
\hline & & $\begin{array}{l}\text { Learning } \\
\text { Motivation }\end{array}$ & $\begin{array}{l}\text { Learning } \\
\text { Outcomes }\end{array}$ \\
\hline \multirow[t]{2}{*}{ Learning Motivation } & $\begin{array}{l}\text { Pearson Correlation } \\
\text { Sig. (2-tailed) }\end{array}$ & 1 & $\begin{array}{r}.908^{* *} \\
.000\end{array}$ \\
\hline & $\mathrm{N}$ & 90 & 90 \\
\hline \multirow[t]{3}{*}{ Learning Outcomes } & Pearson Correlation & $.908^{* *}$ & 1 \\
\hline & Sig. (2-tailed) & .000 & \\
\hline & $\mathrm{N}$ & 90 & 90 \\
\hline
\end{tabular}

\section{Teacher Social Competece Correlate with Student Learning motivation}

The third hypothesis is there is significant correlation between teacher social competence $\left(X_{1}\right)$ and student learning motivation $\left(X_{2}\right)$ in English subject. The hypothesis analyzed based on Pearson's correlation coefficient in table 10 . The correlation is 0.994 which is very strong. Marked by $\left(^{(*}\right)$ means the correlation is significant. In conclusion the third hypothesis that there is significant correlation between teacher social competence on student learning motivation accepted.

Table 10. Coefficients Correlation and Signification Test of $X_{1}$ and $X_{2}$

\begin{tabular}{llrr}
\multicolumn{4}{c}{ Correlations } \\
& \multicolumn{2}{c}{$\begin{array}{c}\text { Teacher Social } \\
\text { Competence }\end{array}$} & $\begin{array}{c}\text { Learning } \\
\text { Motivation }\end{array}$ \\
\hline Teacher Social & Pearson Correlation & 1 & $.994^{* *}$ \\
Competence & Sig. (2-tailed) & 90 & .000 \\
& $\mathrm{~N}$ & $.994^{* *}$ & 90 \\
Learning Motivation & Pearson Correlation & .000 & 1 \\
& Sig. (2-tailed) & 90 & 90 \\
& $\mathrm{~N}$ & &
\end{tabular}

\section{Discussion}

Learning outcome is the goal of the studies to be achieved and product from the learning process which can be seen from the improvement of the behavior obtained after the process of learning (Anni, 2004). Learning outcomes for the students are an improvement of mental development after learning activities including cognitive, affective, and psychomotor, while the teachers are the completion of the learning material that has been delivered (Mudjiono, 2006). Learning outcomes include learning achievement, speed of learning, and affective results (Bloom, 1976). Human characteristics include a typical way of thinking of action and feeling, its related to cognitive, affective, and psychomotor (Anderson, 1981).

The elements included in all three aspects of learning are: (1) learning outcomes in the cognitive: knowledge, comprehension, application, analysis, synthesis, evaluation, (2) learning outcomes in the affective dealing with behavior and score. The students' behavior could be seen from their attention when learning sessions, discipline, learning motivation, how they respect their teacher and classmate. Affective as objectives and types of learning outcomes include: receiving or attending means sensitivity in receiving stimuli from inside and outside, responding or answer, respecting and characteristics that influence personality and behavior, (3) learning outcomes in the psychomotor: in the form of skills, and ability of one's after mastered the cognitive and affective level to the subject (Sudjana, 2005).

For this study, the researcher focuses on learning outcomes in the cognitive area relate to their knowledge. The minimum learning mastery standard for English subject in Junior High School 1 
Purbalingga was 80. The learning outcomes or English Subject of the sample in this study in first semester academic year 2019/2020 as follow:

Table 11. Learning Outcomes in English Subject

\begin{tabular}{cccc}
\hline Range & $\begin{array}{c}\text { Total of } \\
\text { the } \\
\text { Student }\end{array}$ & Grade & Percent \\
\hline $94-100$ & 6 & A & $31.11 \%$ \\
$86-93$ & 56 & B & $62.22 \%$ \\
$79-85$ & 28 & C & $6.67 \%$ \\
$71-78$ & - & D & $0 \%$ \\
$<71$ & - & E & $0 \%$ \\
\hline
\end{tabular}

As shown in table 11 the learning outcomes of students at Junior High School 1 Purbalingga almost all the student pass the minimum learning mastery standard. There are two factors affected students learning outcomes, there are internal and external factors (Slameto, 2010). Internal factors come from inside of the student itself, there are three factors included: (1) physical such as health and disability of the body, (2) psychological such as intelligence, attention, interests, talents, motives, maturity and readiness (3) fatigue that affects physical and psychic. It makes lethargy and boredom drive to the loss of desire to finish the work.

Based on the theory above high or low student result depends on many factors such as their learning motivation. Learning motivation is a process of changing one's behavior or personality based on interactions between individuals and their environment which are carried out formally and informally (Uno, 2007). Learning motivation also an impulse that makes someone do something and to achieve the best learning outcomes. The nature of learning motivation is internal and external encouragement. There are two types of learning motivation, namely: (1) intrinsic motivation comes from inside and does not need external encouragement because every individual already has an urge to do something, (2) extrinsic motivation is an impulse from the outside. the desired goal of behavior that is driven by extrinsic motivation lies outside of that behavior (Sadirman, 2008).

Learning motivation can arise due to intrinsic and extrinsic factors (Uno, 2007), such as: (1) intrinsic factors such as the desire to succeed and the drive for learning needs, hopes for aspirations, (2) extrinsic factors are appreciation, a conducive learning environment, and interesting learning activities. The learning motivation was measured by the desire to be success in English subject, their need in studying, have hope and dreams, have an appreciation for the study, have an interesting activity on studying.

Based on Pearson's correlation coefficient relate to learning motivation and learning outcomes the result is $0.908^{* *}$. The power correlation is very strong. The correlation is positive because there is no minus mark. There is $\left.{ }^{* *}\right)$ signed that the correlation is significant. In conclusion, there is a significant correlation between student learning motivation and learning outcomes for English Subject at Junior High School 1 Purbalingga.

Rumpaka (2016) stated the higher the learning interest the higher students learning achievement. Learning interest is one of the factors that impacted learning motivation. The researcher conducted a study of whether there is an effect of the learning interest on students' learning achievement. The research conducted the study at Junior High School 2 Galur. The population is 187 students while the sample is 127 students selected by means of the proportional stratified random sampling. The instrument of the research is a questionnaire that tested with a product-moment correlation formula and the reliability with the Cronbach's alpha formula. The data were analyzed with simple regression and regression significance used the t-test. The result of the study revealed there is a significant positive effect of the learning interest on the learning achievement based on the regression coefficient of 0.838 and t-observed $=13.628>\mathrm{t}$-table $=1.98$ at a significance of 0.000 , it smaller than 0.05 .

Three external factors affect students learning outcomes, there are: (1) family such as how they parent educate them, the relationship in their family, the environment of their family, and economic stability, (2) The school such as teaching method, curriculum, the relationship between their peer and the teacher, (3) the society such as student activities in the community, media mass, their friend, and lifestyle.

The teacher is associated closely with the student in the implementation of education on daily. The teacher determined student success in achieving the best learning outcomes. Social competence is the teacher's ability to communicate and interact effectively and efficiently with students, peers/professionals, parents of students, and society moreover does not discriminate against ethnicity, race, and language (Kunandar, 2014). Mulyasa (2013) states the teacher's social is an ability to prepare the student to become good members of the community and the ability to educate, guide in facing life in the future. 
Based on Pearson's correlation coefficient relate to teacher social competence and student learning outcomes the result is $0.919^{* *}$. The power correlation is very strong. The correlation is positive because there is no minus mark. There is $\left.{ }^{* *}\right)$ signed that the correlation is significant. In conclusion, there is significant correlation between teacher social competence and student learning outcomes for English Subject at Junior High School 1 Purbalingga.

In accordance with a study done by Maryam (2017) about the influence of teacher social competence toward students learning achievement in Mathematics subjects at Senior High School 1 Narmada academic year of 2016/2017. The study used proportionate stratified random sampling to determine the sample. The sample is 82 students out of 456 students. The study used the ex-post-facto research design. The instrument is a questionnaire with a close-ended answer and final exam $1^{\text {st }}$-semester score as the learning achievement data. The instrument is already been tested the validity and reliability. While for the data analyzed using the normality test, linearity test, and correlation test. The hypothesis was analyzed using simple linear regression. The result shows the student perception of teacher social competence categorizes in the middle with an average value of 48,5244 or $98 \%$. While for student learning achievement in Mathematics subject categorize as strong with an average value of 83 or $83 \%$. The hypothesis shows there is significant influence between teacher social competence and student learning outcomes in Mathematics subject at Senior High School 1 Narmada academic year 2016/2017 for about f-distribution 9.027 and f-table 3.96.

A competent teacher is a teacher who can influence students positively in learning. Not only the student but also the parent and the community. To achieve all of that a teacher needs to have communication skills and get along with the students, peers, and parents. For the student, they should motivate their self to get the best result.

Based on Pearson's correlation coefficient relate to teacher social competence and student learning motivation the result is $0.994^{* *}$. The power correlation is very strong. The correlation is positive because there is no minus mark. There is $\left(^{* *}\right)$ signed that the correlation is significant. In conclusion, there is significant correlation between teacher social competence and student learning motivation.

Tabi'in (2016) stated that a competent teacher with a good environment improving the student learning motivation. There are several ways to motivate students that have been done by the teacher giving gifts, approaching, raising enthusiasm for learning, directing learning activities, giving praise. This study used a qualitative approach. The data collection procedures are in-depth interview techniques, participant observation, and documentation. The sample of the study is students at Madrasah Tsanawiyah State Pekan Heran Indragri Hulu. The data were analyzed using data reduction, data presentation, and drawing conclusions. The school here gives freedom to choose the strategies, method, learning techniques, and the most effective teaching technique according to the characteristics of the subjects and teacher's background education.

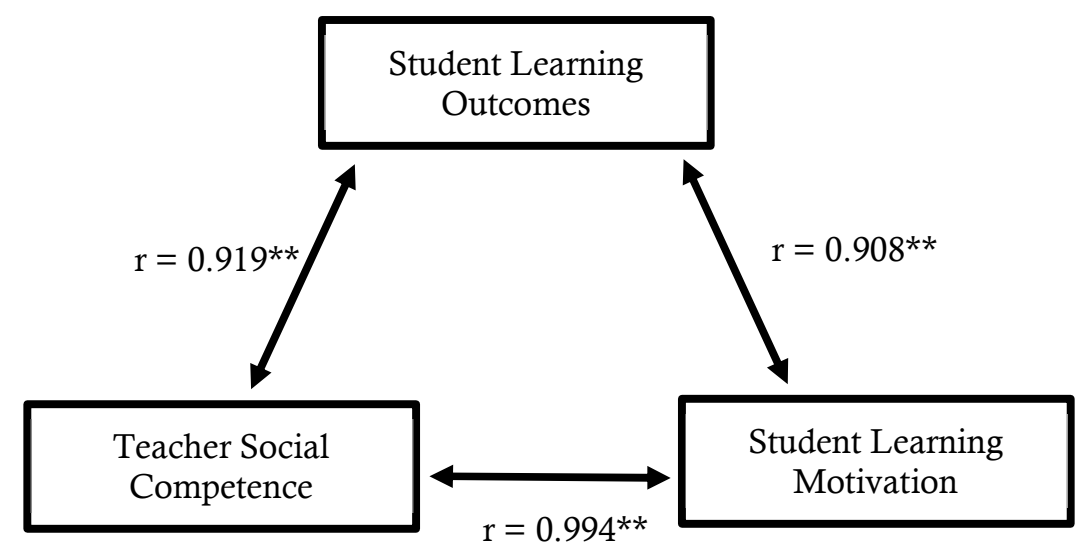

Figure 1. The Result of Hypotheses Test

As the final result, teacher social competence, student learning motivation and student learning outcomes correlation are positive, significant and very strong. Teacher social competence correlate for 0.919 on student learning outcomes, student learning outcomes correlate for 0.908 on student learning outcomes and teacher social competence correlate with student learning motivation for 0.994. The result show that teacher social competence correlation is higher than student learning motivation. In that case, teacher should working on their social skill to improve student learning outcomes. However, the student also need to keep motivate their self because the correlation itself is very strong. All in all, teacher social competence and 
student learning motivation is influence student learning outcomes in English subject at Junior High School 1 Purbalingga.

\section{CONCLUSION}

Based on the result of the study and discussion, the researcher drawn a conclusion as follow: (1) there was a positive and significant correlation between teacher social competence and student learning outcomes at Junior High School 1 Purbalingga on English subject as indicated by the correlation coefficient ( $\mathrm{r}$ ) of 0.919 , (2) there was also a positive and significant correlation between student learning motivation and student learning outcomes at Junior High School 1 Purbalingga on English subject as indicated by the correlation coefficient (r) of 0.908 , (3) there was a positive and significant correlation between teacher social competence and student learning motivation at Junior High School 1 Purbalingga on English subject as indicated by the correlation coefficient (r) 0.994 .

Based on the findings and the conclusion of this study, the researcher made the following suggestion: (1) teacher should improve their social competence, especially for their communication skill to develop their relationship with their student and build a friendly environment around the class and school. Student should maintain their learning motivation to get the best result, (2) the student could boost their motivation by raising their interest in English subject, doing fun activities related to English language such as listening to music, watching films, playing games and many others, (3) for other researchers, you could find out another research dealing with teacher social competence, (4) for future research, it is suggested to investigate other factors that affect student learning outcomes.

\section{REFERENCES}

Adi, B. (2019). Questionnaire: Definition, examples, design and types [Weblog]. Retrieved from https://www.questionpro.com/blog/what-is-a-questionnaire/

Anderson, J. R. (1981). A theory of language acquisition based on general learning principles. Pittsburgh: CarnegieMellon University.

Anni, C. T. (2004). Psikologi belajar. Semarang: UPT MKK UNNES.

Bernaus, M., \& Gardner, R. C. (2008). Teacher motivation strategies, student perceptions, student motivation, and English achievement. The Modern Language Journal, 92(3), 387-401.

Bloom, B. S. (1976). Human characteristics and school learning. New York: McGraw-Hill.

Chang, M.C., Shaeffer, S., Al-Samarrai, S., Ragatz. A.B., Ree, J.D., \& Steveson, R. (2014). The role of politics and evidence in policy making. Washington DC: The World Bank.

Dudovskiy, J. (2016). The ultimate guide to writing a dissertation in business studies: A step-by-step assistance. English: Reasearch-Methodology. Retrieved from https://www.research-methodology.net

Hakim, A. (2015). Contribution of competence teacher (pedagogical, personality, professional competence and social) on the performance of learning. The International Journal of Engineering and Science (IJES), 4(2), 1-12.

Kunandar, E. (2014). Guru profesional. Jakarta: Rajawali Press.

Mansur, H. R. (2009). Penilaian hasil belajar. Bandung: Wacana Prima.

Mappeasse, M. Y. (2009). Pengaruh cara dan motivasi belajar terhadap hasil belajar Programmable Logic Controller (PLC) siswa kelas III jurusan listrik SMK Negeri 5 Makassar. Jurnal Medtek, 1(2), 1-6.

Maryam, S. (2017). Pengaruh kompetensi sosial guru terhadap prestasi belajar Matematika pada siswa SMAN 1 Narmada tahun pelajaran 2016/2017 (Thesis, Universitas Islam Negeri Mataram, Mataram, Indonesia). Retrieved from http://www.uinmataram.ac.id

Muda'i, A. (2017). Pengaruh kompetensi personal guru dan kompetensi sosial guru terhadap motivasi belajar siswa pada mata pelajaran pendidikan agama Islam kelas XI di SMA Dharma Wanita Kediri (Thesis, AIN Kediri, Kediri, Indonesia). Retrieved from http://www.etheses.iainkediri.ac.id

Mudjiono, D. (2006). Proses belajar mengajar. Jakarta: Bumi Aksara.

Mulyasa, E. (2013). Uji kompetensi dan penilaian kinerja guru. Bandung: Remaja Rosdakarya.

Musriana. (2018). Pengaruh guru sebagai motivator terhadap hasil belajar siswa pada mata pelajaran Akuntansi kelas XI IPS di SMA Negeri 12 Makassar (Thesis, Uiversitas Negeri Makassar, Makassar, Indonesia). Retrieved from http://www.eprints.unm.ac.id

Pratama, H. (2019). Statistika pada bidang bahasa. Semarang: UNNES Press.

Rumpaka, I. A. (2016). Pengaruh minat belajar terhadap prestasi belajar IPS siswa kelas VIII SMP N 2 Galur (Thesis, Universitas Negeri Yogyakarta, Yogyakarta, Indonesia). Retrieved from http://www.eprints.uny.ac.id

Sadirman, A. M. (2008). Interaksi dan motivasi belajar mengajar: Pedoman bagi guru dan calon guru. Jakarta: Rajagrafindo. 
Slameto. (2010). Belajar dan faktor-faktor yang mempengaruhinya. Jakarta: Bina Aksara.

Sudjana, N. (2005). Dasar-dasar proses belajar mengajar. Bandung: Sinar Baru.

Sugiyono. (2010). Statistik untuk pendidikan. Bandung: Alfabeta.

Sugiyono. (2015). Metode penelitian kuantitatif kualitatif dan r\&d. Bandung: Alfabeta.

Sujarweni, W. (2014). SPSS untuk penelitian. Yogyakarta: Pustaka Baru Press.

Tabi'in, A. (2016). Kompetensi guru dalam meningkatkan motivasi belajar pada MTsn Pekan Heran Indragri Hulu. Jurnal Al-Thariqah, 1(2).

Uno, H. B. (2007). Teori motivasi dan pengukuran. Jakarta: Bumi Aksara.

Uno, H. B., \& Lamatenggo, N. (2016). Tugas guru dalam pembelajaran. Jakarta: Bumi Aksara.

Wardani, S. F., Ulfah, M., \& Okianna, O. (2018). Pengaruh kompetensi sosial guru terhadap motivasi belajar siswa kelas XI jurusan Akuntansi SMK Negeri. Jurnal Pendidikan dan Pembelajaran, 7(5).

Widiyanto, J. (2012). SPSS for windows. Surakarta: Badan Penerbit-FKIP Universitas Muhamadiyah Surakarta. 